\title{
Euthanasia: Moral and Legal Aspects
}

\section{Sumachev AV*}

Doctor of law, Professor of Criminal Law and Criminal Procedure, Ugra State University, Russia

*Corresponding author: Alexey Vitalyevich Sumachev, Doctor of law, Professor of Criminal Law and Criminal Procedure, Ugra State University, 628012, Khanty-Mansiysk, Russia, Tel: 8-922-478-71-22; Email: alekssumachev@mail.ru

\section{Research Article}

Volume 4 Issue 1

Received Date: March 05, 2021

Published Date: March 23, 2021

DOI: $10.23880 /$ abca-16000171

\section{Abstract}

The practice of artificially taking the life of a person suffering from an incurable disease and experiencing unbearable suffering as a result of this disease is traditionally called euthanasia. At the same time, such actions were evaluated and are currently evaluated ambiguously both from the standpoint of moral and legal. Accordingly, the issues of euthanasia (as well as causing death with the consent of a person in general) should be solved from the standpoint of their comprehensive research (not only from the standpoint of directly legal, but also from the point of view of philosophy, morality, religion, psychology, medicine). The article presents the data of our own research on the criminal-legal meaning of a person's consent to the death of another person. At the same time, it is stated that the public opinion of citizens is inclined to the non-criminality of taking the life of another person with his consent. In turn, experts-supporters of the legalization of euthanasia - along with arguments of a moral and moral nature point directly to the legal aspects. At the same time, the article states that the absolute prohibition of euthanasia (including any kind of deprivation of life with the consent of a person) is justified. Accordingly, it is concluded that the implementation of euthanasia should not exclude the criminality of the act, which, of course, is regarded as murder. At the same time, it is noted that for cases of deprivation of life in the implementation of euthanasia, legal rules should be provided for mitigating the reaction to the actions of the harm-causing agent.

Keywords: Artificial Deprivation of Human Life; Euthanasia; Public Opinion of Citizens; Legalization of Euthanasia; Unconditional Prohibition of Euthanasia, Mitigation of Criminal Liability

\section{Introduction}

Among the main human rights, the most significant is undoubtedly the right to life as it was aptly noted: "The right to life has several aspects, including the right to preserve life (identity) and the right to dispose of life" [1]. In turn, the disposal of this right is possible in two ways:

- Taking your own life (suicide);

- Consent to the deprivation of life by a third person (a type of which is euthanasia-translated from Greek means-a happy, easy death. In the modern interpretation, euthanasia is associated only with the deprivation of the life of a terminally ill person with his consent by a doctor in order to alleviate the suffering of such a patient [2-4]).
The first of them suicide-is not recognized as a crime in the modern legislation of almost all countries. Regarding euthanasia, the legislation of different states solves this problem in differentways. In some countries, euthanasia is not recognized as a crime (of course, if appropriate procedures are followed) (the Netherlands); in other states, taking life with the consent of the victim (including euthanasia) is recognized as a privileged type of murder (with mitigating circumstances) (Germany, Spain, etc.); Thirdly, any cases of causing death with consent are considered ordinary murder (France, Sweden, etc.). In Russia, in the period before 1917, murder with consent was recognized as a privileged type (Article 455 of the Criminal Code of 1903). The first Soviet Criminal Code of the RSFSR of 1922 contained a special note 
to Article 143, according to which" murder committed at the insistence of the victim out of a sense of compassion is not punishable" [5]. However, a few months later, this note was removed from the criminal law, and this kind of murder was considered as ordinary. This situation continues to the present day. Note that this legislative decision has a number of supporters [6-8], as well as opponents [9-11].

\section{Materials and Methods}

The main sources for writing this article are the current Criminal Code of the Russian Federation, the Criminal Code of the Federal Republic of Germany, the Criminal Code of Spain, the Criminal Code of France and the Criminal Code of Sweden, as well as the materials of monographic studies and journal publications.

In the course of the research, the main methods of cognition were used: problem-chronological, systematic and comparative law. The author's reasoning is based on the problem-chronological approach. The application of the systematic method allowed integrating the achievements of various fields of knowledge (criminal law, philosophy, morality, religion, psychology, medicine) into the criminal law doctrine and formulating conclusions on the problems posed in the article.

\section{Legalizing Euthanasia: Arguments for and against}

Undoubtedly, the issues of euthanasia (as well as causing death with the consent of a person in general) should be solved from the standpoint of their comprehensive research (not only from the standpoint of directly legal, but also from the point of view of philosophy, morality, religion, psychology, medicine). We are interested in the moral and legal aspect of the issue of euthanasia in general and the criminal and legal aspects of this problem in particular.

The law is not only an unchangeable reality; it reflects the existing system of values and attitudes in the country, that is, the totality of social relations as a whole. In this regard, the conditionality of the criminal law in the part "for and against" the punish ability of causing death with the consent of a person is of direct interest to criminal law. However, it can be noted that the focus of special research on the issues of causing death with consent was limited only to the problem of euthanasia $[4,3,8,10,12-14]$.

So, according to Maleina NM, et al. [15], in 1992, 72\% of respondents in the UK are ready to approve euthanasia under certain circumstances. In France, this number is $76 \%$ of respondents. In the US, there were 6 of them in the proportion: In Russia at that time, the society was not even ready to raise this issue [15]. A more recent study of the public opinion of Russians on the problem of euthanasia, cited by Ardasheva NA, et al. [14] indicates that $77 \%$ of respondents learned about this problem from the press, $10 \%$ in the process of everyday communication, and for $12 \%$ euthanasia is of interest at the professional level. At the same time, $80 \%$ of respondents, supporting euthanasia, noted that within the framework of Russian society, the legislative consolidation of such would be premature.

\section{Own Research on the Criminal-Legal Meaning of a Person's Consent to the Death of another Person}

When conducting our own research, the question was raised somewhat more broadly. In particular, among others, the question of the criminal-legal meaning of a person's consent to the death of another person was raised. At the same time, $7.5 \%$ of men indicate that the deprivation of life by consent should be punishable as ordinary murder, $6.8 \%$ note the need for only mitigation of punishment in such cases, $5.2 \%$ say that all cases of deprivation of life by consent are not punishable, and $31.4 \%$ only about the non-criminality of individual cases of such acts (deprivation of life by a doctor of a terminally ill patient at his request (euthanasia) -18.7\%; deprivation of life of an inferior newborn child at the request of his parents $-10.3 \%$ ).\%; the loss of life of a seriously injured person during an extreme situation (military operations, natural disasters, etc.) $-5.9 \%$; the loss of life of a person-the object of a scientific experiment during such an experiment $-2.4 \%)$.

In women, the situation is almost similar: $8.9 \%$ indicate that the deprivation of life by consent should be punishable as ordinary murder, $6.8 \%$ determine the need for only mitigation of punishment in such cases, $3.7 \%$ say that all cases of deprivation of life by consent are not punishable, and $32.4 \%$ only about the non-criminality of individual cases of such acts (respectively, the doctor's deprivation of the life of a terminally ill patient at his request (euthanasia) $19 \%$; the deprivation of the life of an inferior newborn child at the request of his parents $-11.9 \%$ ).\%; the loss of life of a seriously injured person during an extreme situation (military operations, natural disasters, etc.) $-3.8 \%$; the loss of life of a person-the object of a scientific experiment during such an experiment $-2.2 \%$ ).

Thus, $16.4 \%$ of the surveyed citizens do not draw the line between murder with consent and ordinary murder, $10.9 \%$ see the difference only in the possibility of mitigating the punishment for the first cases. The absolute majority-72.7\% is either in favor of non-punish ability of all types of murder with consent $(8.9 \%)$, or for non-punish ability of certain types of it $(63.8 \%)$. 
As a general result, it can be stated that the public opinion of citizens is inclined to the non-criminality of taking the life of another person with his consent and from the point of view of the majority of modern legal scholars who have addressed this issue, the legalization, in particular, of euthanasia, seems appropriate [16]. However, some researchers advocate a more liberal approach to legalizing euthanasia. Thus, Borodin S, et al. [12,13,17], a more cautious approach to the legislative authorization of euthanasia to legalize its individual forms, fixing in the criminal law the privileged composition of murder out of compassion. It is worth noting that in one of the drafts of the Criminal Code of the Russian Federation, Article 106 "Deprivation of life by the will of the victim" was even proposed, which, however, is not reflected in the modern criminal law.

Supporters of the legalization of euthanasia, in addition to arguments of a moral and moral nature, point out directly legal ones. Thus Kondrashova TV, et al. [4] notes:

- Since the law provides for the right to life, and the right to a good implies the disposal of this good at one's own discretion, this presupposes the existence of the right to death;

- Recognizing the right to death of physically healthy persons, the Russian legislation deprives such a right of persons who are in a helpless state and are unable to independently implement their voluntary volitional decision to give up life, which violates the principle of equality of citizens before the law.

In contrast to the opinion expressed, the following can be pointed out:

- The right to die is not the "reverse side of the right to life" for two reasons: first, a person's life is not his private good, since a person is a person, that is, a "social person" who not only "lives" in society as a physiological being, but also owes something to this society; in this regard, and, secondly, the right to life is guaranteed by the state, moreover, conditions are created that ensure human life. The conditions that ensure the death of a person are not provided for in organizational and legal practice;

- Violations of the principle of equality of citizens before the law in terms of the exercise of the right to death by a physically healthy and helpless person are not seen here. If you follow from the opposite, then doctors should not establish a hospital regime in medical institutions, the regime of taking medicines and undergoing medical procedures, because the legal status of a patient undergoing inpatient treatment and a physically healthy person should be exclusively the same;

- We do not deny the possibility of fulfilling the desire to "leave" life (the right to die), but we believe that it should be inherent in a physically healthy person, and

\author{
implemented by him only independently.
}

The medical commandment from the "Hippocratic Oath". "I will not give anyone a deadly poison asked of me.... Historically determined for almost 25 centuries the views of doctors on the prohibition of euthanasia. Article 45 of the "Fundamentals of the Legislation of the Russian Federation on the protection of Citizens "health" also explicitly defines such a ban: "Medical personnel are prohibited from performing euthanasia satisfying the patient's request to accelerate his death by any actions or means, including the termination of artificial measures to maintain life. A person who deliberately encourages a patient to euthanize and/or performs euthanasia is criminally liable in accordance with the legislation of the Russian Federation" [18]. Is this ban justified? In the words of Kovalev MI, et al. $[8,19]$ : "There are no strong arguments against declaring that a person has the right to life and to death". Arguments in favor of banning or legalizing euthanasia are based, to a greater extent, on the personal attitudes of the person. At the same time, the arguments used by Kovalev MI, et al. [8,19] can be cited in favor of the expediency of banning euthanasia:

- The error of a huge number of diagnoses;

- The terminal and pre-terminal stages are often associated with a special state of the human body and have not been studied by medicine;

- Due to the rapid development of medicine and pharmacology, some diseases, even yesterday absolutely and relatively fatal, are now subject to final cure;

- The main purpose of the doctor is to be an assistant to a person in preserving life. We fully share M. I.'s position. We believe that the absolute prohibition of euthanasia (including any kind of deprivation of life with the consent of a person) is justified.

On the other hand, medical practice in foreign countries, where euthanasia is prohibited, has examples of its implementation by medical professionals. Individual acts of euthanasia, according to Kondrashova TV, et al. [4] took place in the USSR, but did not become the subject of judicial review (despite the prohibition of such actions by law) due to the fact that persons who were aware of this did not report it to law enforcement agencies. Semerneva also testifies to the presence of such cases in Russian medical practice in relation to "newborns with disabilities, inferiors, as well as terminally ill patients who clearly and distinctly expressed their desire for death" [18]. Yu A, et al. [11], generally talk about 20-30 thousand cases of euthanasia per year. These evidences lead to two conclusions. First, although cases of euthanasia are not widespread, they occur not only in medical practice, but also in everyday reality. Secondly, the failure to criminalize the perpetrators of acts of euthanasia is not based on the law, but on some personal relationships. 


\section{Results}

Thus, the implementation of euthanasia should not exclude the criminality of the act, which, of course, is regarded as murder. However, since a person's life is not only his private good, but also the highest social value protected by the state (Article 2, Part 1 of Article 20 of the Constitution of the Russian Federation), there should be a reaction even to isolated cases of euthanasia. In view of the fact that "it is impossible to put on the same level with a murderer out of greed or revenge, a soldier who stabbed his mortally wounded comrade on the battlefield at his request, in order to save him from further torment, a doctor who stopped the agonizing agony of a dying person, etc. [9], for cases of deprivation of life in the implementation of euthanasia, legal rules should be provided for mitigating the reaction to the actions of the harm-causer.

We can suggest an organizational and practical way to solve this problem:

- The fact of euthanasia must be taken into account by the judge when assigning punishment to the guilty person as a mitigating circumstance that characterizes the "motive of compassion" (paragraph "d" of Part 1 of Article 61 of the Criminal Code);

- The fact of euthanasia must necessarily be taken into account as an "exceptional circumstance" in the sense of Article 64 of the Criminal Code of the Russian Federation, which also allows for a significant reduction in the penalty.

Moreover, the same rule should be extended to all cases of deprivation of life with the consent of a person. This is the legal aspect of the issue of euthanasia from the standpoint of the current legislation, which we fully share.

\section{References}

1. Kovalenko SE (1999) Death-a natural right?. Actual problems of jurisprudence: Interuniversity collection of scientific articles. Tyumen: Tyumen Publishing House 4: 43-51.

2. Lebedev RN, Belorusov OS, Bochkov NP, Bunyatyan AA (1988) Deontology in clinical resuscitation Chapter 7. Deontology in medicine, General deontology. Moscow: Meditsina 4(1): 352.

3. Euthanasia F (1990) Philosophical Sciences 6: 63-80.

4. Kondrashova TV (2000) Problems of criminal responsibility for crimes against life, health, sexual freedom and sexual inviolability. Yekaterinburg: Humanitarian University, pp: 348.

5. Chistyakov OI (2009) Domestic legislation of the XI-XX centuries: Part 2. 11th century manual for seminars. Moscow: Yurist, pp: 347.

6. YaA (1990) Professional ethics in medicine. Philosophical essays, pp: 220.

7. Kotelnikov V.P (1987) From Hippocrates to the present day. Moscow, pp: 109.

8. Kovalev MI (1992) The right to life and the right to death 7: 68-75.

9. Tagantsev NS (1994) Russian criminal law. Lectures: General part, pp: 380.

10. Zilber AP (1998) A treatise on euthanasia, containing arguments about easy serene death, thought out and written by the author in the hours free from worries about prolonging life. Petrozavodsk: Petrozavodsk State University Publishing House, pp: 463.

11. Dmitriev YA, Shleneva EV (2000) Human right in the Russian Federation to implement euthanasia 11: 52-59.

12. Borodin S, Glushkov V (1992) Murder from compassion and the problem of euthanasia. Social Sciences and Modernity 4: 138-145.

13. Borodin S, Glushkov V (1992) Criminal-legal problems of euthanasia. Modern Justice 9(10): 340.

14. Ardasheva NA (1996) Euthanasia as a method of artificial interruption of life: legal conditions. Russian Law Journal 1(9): 71-80.

15. Maleina NM (1992) On the right to life. The Soviet State and Law 2: 50-59.

16. Maleina MN (1991) Protection of personal non-property rights of Soviet citizens. Manual for students of national universities. Moscow: Znanie, pp: 127.

17. Borodin SV (1999) Crimes against life. Moscow: Yurist, pp: 356.

18. (1993) Osnovy zakonodatelstva Rossiyskoy Federatsii o okhranykh zdorovya grazhdanii. Vedomosti Konezda narodnykh deputatov Rossiyskoy Federatsii i Verkhovnogo Soveta Rossiyskoy Federatsii ot 33: 1318.

19. Kovalev MI, Kozachenko ZA, Neznamova M (1997) Criminal law. General part: Textbook for universities. INFRA-M: Norma, pp: 503. 